[Research Note]

\title{
Adsorptive Separation of Infinitesimal Sulfur Oxide in Naphtha -Reactivation of Silica Gel Using Toluene and Dimethyl Ether-
}

\author{
Akimitsu Matsumura ${ }^{\dagger 1)}$, Kazumasa YazU ${ }^{\dagger 1)}$, Shinya $\mathrm{SATO}^{\dagger 1) *}$, and Hiroaki $\mathrm{TAO}^{\dagger 2)}$ \\ 1) Advanced Fuel Group, Energy Technology Research Institute, National Institute of Advanced Industrial Science and Technology, \\ 16-1 Onogawa, Tsukuba, Ibaraki 305-8569, JAPAN \\ 2) Measurement Technology Group, Research Institute for Environmental Management Technology, \\ National Institute of Advanced Industrial Science and Technology, 16-1 Onogawa, Tsukuba, Ibaraki 305-8569, JAPAN
}

(Received August 4, 2008)

\begin{abstract}
Adsorption of sulfur oxide is one of the key techniques for producing extra-low-sulfur content naphtha during oxidative desulfurization. Reactivation and repeated use of adsorbent are quite important for practical and economic reasons. The reactive performance of silica gel (SIL), an excellent adsorbent for the adsorption of benzothiophene-1,1-dioxide (BTDO), a model sulfur oxide, was evaluated using toluene and dimethyl ether (DME) by multicycle adsorption-reactivation tests. In an 8-cycle adsorption-reactivation test using toluene as a reactivation agent, the breakthrough amount after 8 cycles was reduced to $68 \%$ of the first cycle. Using DME, the breakthrough amount was reduced to $87 \%$ at the second run based on the first run, but this level was maintained throughout the remaining cycles. Three types of naphtha, Naphtha A, hydrotreated naphtha (Naphtha B), and a 50\% mixture, were tested in 8-cycle tests using DME as a reactivation agent. The breakthrough amount of SIL was as high as 1300-1700 g/g-SIL for Naphtha A, and 500-1000 g/g-SIL for Naphtha B containing $13 \mathrm{wt} \%$ of aromatics. The breakthrough amount for the mixture was almost the same as for Naphtha A. These results suggest that SIL is suitable for naphtha containing up to $7 \mathrm{wt} \%$ of aromatics. A 25-cycle adsorption-reactivation test was performed using Naphtha A by limiting the throughput to $1300 \mathrm{~g} / \mathrm{g}$-SIL. During the 25 cycles, no significant amount of BTDO was observed in any of the treated naphtha products.
\end{abstract}

\section{Keywords}

Oxidative desulfurization, Adsorption, Naphtha, Dimethyl ether, Reactivation, Silica gel

\section{Introduction}

The introduction of fuel cells for powering vehicles is expected to solve many of the environmental problems caused by conventional vehicles ${ }^{1)}$. However, one of the more important unresolved issues in the development of fuel cell technology is that of ensuring a constant supply of hydrogen. Liquid fuels, such as gasoline, have clear advantages: The infrastructure of conventional gas stations can be used for on-site or onboard conversion, and the conversion efficiencies are higher. Moreover, although hydrogen can be produced at lower cost than the equivalent quantity of methanol, the sulfur levels must be reduced to several $10 \mathrm{ppb}$ for use in fuel cells.

The issue of desulfurization has been extensively investigated in the past decade, and the oxidative desulfurization (ODS) method has been developed ${ }^{6) \sim 8)}$. Much of the effort has been directed at ultra-deep de-

\footnotetext{
* To whom correspondence should be addressed.

* E-mail: s-sato@ aist.go.jp
}

sulfurization of gas oils, but some studies have also examined naphthas. ODS should eventually prove effective for reducing sulfur compounds at relatively low temperatures under atmospheric pressure. The combination of oxidation with post-oxidation treatments such as adsorption should allow concentrations of $20 \mathrm{ppb}$ or lower ${ }^{9 \sim 12)}$, with far less stringent conditions than those required for hydrodesulfurization (HDS). If the feedstock used for ODS already has a low sulfur concentration, sulfur-free fuels can be produced with minimal loss.

Previously, we applied ODS to a hydro-treated naphtha that contained low concentrations of aromatic compounds $(<1 \mathrm{wt} \%)$, no olefins, and $10 \mathrm{ppm}$ sulfur. The oxidation process should reduce the initial sulfur concentration to about $1 \mathrm{ppm}^{11)}$. Subsequent adsorption separation should reduce the sulfur oxide level to $10 \mathrm{ppb}$ to yield extra-low-sulfur naphtha. Therefore, we studied the adsorption separation of benzothiophene1,1-dioxide (BTDO), the oxidation product of benzothiophene, which tends to persist in naphtha after $\mathrm{ODS}^{11)}$, and showed that silica gel (SIL) was quite good 
at adsorbing the contaminating BTDO from naphtha ${ }^{12)}$ because of the high adsorption breakthrough amount, power, and rate. Silica-alumina and silica gel are also effective to remove oxidized sulfur compounds from $\mathrm{LGO}^{10)}$, but the reactivation of adsorbents was not investigated. From the viewpoint of practical and economical use, reactivation and repeated use of adsorbent is quite important. We previously found that dimethyl ether (DME), unlike butane, is an excellent solvent for the extraction of phenols from water using a pressureswing extraction process ${ }^{13)}$. Therefore, DME is also effective for the reactivation of SIL, although the reactivation of adsorbent using DME has not been established. The present study examined the use of DME for the reactivation of SIL

\section{Materials and Experiment}

\section{1. Reagents and Adsorbents}

Silica gel was used as an adsorbent (SIL, Davison silica gel 923), and benzothiophene-1,1-dioxide (BTDO, $\mathrm{C}_{8} \mathrm{H}_{6} \mathrm{SO}_{2}$; formula weight, 166.1; SigmaAldrich Japan, K.K.) as a sulfur oxide model. The eluents for high performance liquid chromatography (HPLC) analysis and reagents for the model naphtha were as described previously. DME (Tomoe Shokai) was purchased in a $12-l$ cylinder.

Two types of base naphtha were used in the test: Model naphtha prepared in the same manner reported previously, and hydrodesulfurized straight-run naphtha prepared by $\mathrm{HDS}$ using a $\mathrm{Co}-\mathrm{Mo} / \mathrm{Al}_{2} \mathrm{O}_{3}$ catalyst. The HDS reaction conditions were as follows: reaction temperature, $493 \mathrm{~K}$; reaction pressure, $3 \mathrm{MPa}$; liquid hourly space velocity (LHSV), $6 \mathrm{~h}^{-1}$; and $\mathrm{H}_{2} /$ oil ratio, $150 \mathrm{~N} / / l$.

The test samples were prepared by mixing $1 \mathrm{wt} \%$ of toluene containing $500 \mathrm{ppm}$ of BTDO with both the model and the hydrodesulfurized straight-run naphthas. The sulfur concentration of both test samples was about $1 \mathrm{ppm}$. The composition of the model sample (Naphtha A) is shown in Table 1, and the properties of the hydrodesulfurized straight-run naphtha (Naphtha B) are shown in Table 2.

\section{2. Adsorption Test}

The continuous-flow adsorption test unit (Fig. 1) and the test procedure were as previously described ${ }^{12)}$. The typical procedure was as follows. The model naphtha was fed from a feed pump (A) at $0.3 \mathrm{ml} / \mathrm{min}$, and after passing through the adsorption column, was sampled every $20 \mathrm{~min}$ using valve D in Fig. 1. The sample was analyzed by HPLC using the same procedure as in the preliminary runs. The BTDO concentration in the effluent was measured using a UV detector. The detection limit of this system was approximately $5 \mathrm{ppb}$ for BTDO, or approximately $1 \mathrm{ppb}$ sulfur. The BTDO concentration in the recovered naphtha was estimated by integrating the BTDO concentration curve
Table 1 Composition of Model Naphtha

\begin{tabular}{lc}
\hline \multicolumn{1}{c}{ Component } & Concentration [wt \%] \\
\hline Methylcyclohexane & 15 \\
Heptane & 13 \\
Ethylcyclohexane & 25 \\
Octane & 7 \\
Isopropylcyclohexane & 15 \\
Nonane & 15 \\
Decane & 10 \\
Toluene & 1 \\
BTDO & \\
\hline
\end{tabular}

Table 2 Properties of Hydrotreated Naphtha

\begin{tabular}{lrc} 
Boiling range & & $70-151^{\circ} \mathrm{C}$ \\
Density & {$\left[\mathrm{g} / \mathrm{cm}^{3}, 20^{\circ} \mathrm{C}\right]$} & 0.73 \\
Type distribution & {$[\mathrm{wt} \%]$} & \\
Alkanes & 67.1 \\
Olefins & 0.8 \\
Naphthenes & 19.0 \\
Aromatics & 13.1 \\
Toluene & 1.0 \\
BTDO & $5 \mathrm{ppm}(1 \mathrm{ppm}-\mathrm{S})$ \\
\hline
\end{tabular}

with time. The criterion used for evaluation was the throughput per gram of adsorbent necessary for the sulfur concentration to reach $10 \mathrm{ppb}$ in the recovered naphtha (breakthrough amount).

To confirm the experimental method, a preliminary test with 4-cycle adsorption-desorption test was performed prior to multiple repeated experiments. In the test, Naphtha A was used as feed, and SIL was reactivated by toluene. The recovery of BTDO was evaluated by the determination of toluene used for the reactivation and recovered Naphtha A using HPLC with an UV detector (Line B, E and F in Fig. 1). In addition, the BTDO concentration on SIL was estimated at the point recovered Naphtha A had a BTDO concentration of $10 \mathrm{ppb}$.

\section{3. Reactivation Test Using Toluene and DME}

Adsorption-reactivation tests were repeated for several cycles using toluene and DME as the respective reactivation solvents. For the toluene test, SIL with adsorbed BTDO was reactivated by passing $10 \mathrm{~m} l$ toluene through the column at $0.5 \mathrm{ml} / \mathrm{min}$, and then the toluene was replaced with $5 \mathrm{~m} l$ of $n$-hexane. For the DME test, $15 \mathrm{ml}$ of liquid DME was passed through the column over about $10 \mathrm{~min}$ with the outlet pressure of the column maintained at about 0.6 MPa (Fig. 2). The column was stood for $30 \mathrm{~min}$ at normal pressure to remove any gaseous DME. The reactivation perfor- 
mance was evaluated by comparing the breakthrough amount with that of the first cycle (breakthrough ratio).

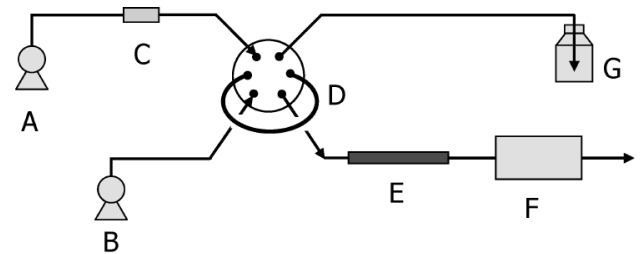

$\begin{array}{lll}\text { A Feed pump } & \text { B Analytical pump } & \text { C Adsorption column } \\ \text { D Sampling valve } & \text { E Analytical column } & \text { F UV detector } \\ \text { G Receiver } & & \end{array}$

Eluent: $30 \mathrm{vol} \%$ ethanol $/ \mathrm{n}$-hexane. Flow rate: $0.3 \mathrm{~m} / / \mathrm{min}$. Analytical column: Inertsil 3, $2.1 \mathrm{~mm}$ (i.d.) $\times 250 \mathrm{~mm}$. Sampling loop: $20 \mu l$. Wavelength of UV detector: $300 \mathrm{~nm}$.

Fig. 1 Schematic Diagram of Continuous-flow Adsorption Test Unit

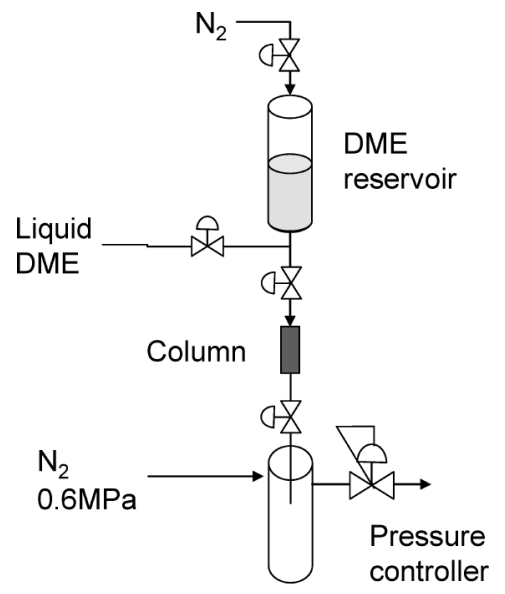

Receiver at $0.6 \mathrm{Mpa}$

Fig. 2 Simplified Diagram of Activation Apparatus Using DME

\section{Results and Discussion}

\section{1. Preliminary Test}

The typical correlation between the sulfur concentration in the recovered naphtha and the throughput is shown in Fig. 3. The breakthrough amount is about $1500 \mathrm{~g} / \mathrm{g}$-SIL in this figure. The test estimated the BTDO concentration at the breakthrough point, and the recovery of BTDO by reactivation using toluene. More than $90 \%$ of the BTDO feed was contained in the toluene used for the reactivation, and $1.7-6.3 \%$ in the treated Naphtha A (Table 3). The loss of BTDO was 3.4-7.1 wt $\%$ in each cycle. These results show that the adsorption test was carried out correctly. Table 3 also shows that the BTDO concentration adsorbed on SIL was $0.55-0.85 \mathrm{wt} \%$ based on SIL.

\section{2. Reactivation with Toluene and DME}

Two runs of the 8-cycle reactivation test were performed using Naphtha A. In the first cycle, fresh SIL activated by drying at $130^{\circ} \mathrm{C}$ overnight was used, and the breakthrough amount was $1300-1700 \mathrm{~g} / \mathrm{g}$-SIL. After reactivation using toluene, the breakthrough ratio in the second cycle was about $80 \%$, and decreased by about $3 \%$ in each subsequent cycle, with an overall breakthrough ratio of $68 \%$ after 8 cycles (Fig. 4). Those results showed that toluene could not fully re-

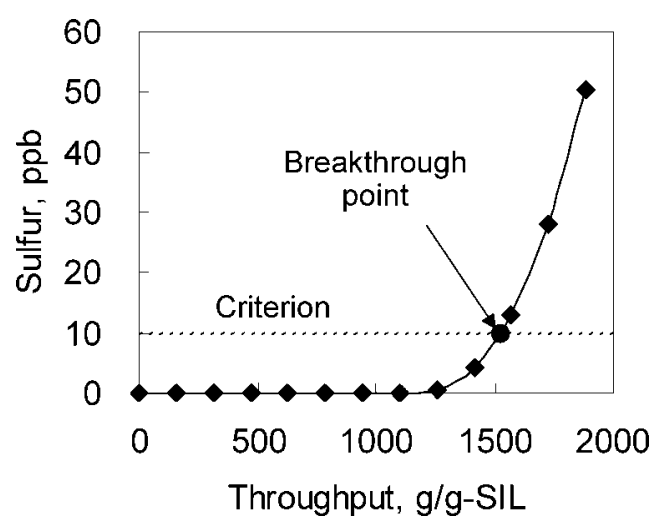

Fig. 3 Typical Profile of Sulfur Concentration with Throughput

Table 3 Recovery of BTDO and the Concentration on SIL in the Prelimina

\begin{tabular}{cccccc}
\hline & & \multicolumn{3}{c}{ Recovery $^{\mathrm{a})}$} & \multicolumn{2}{c}{ BTDO $^{\mathrm{b})}$ on SIL [\%] } \\
\cline { 3 - 5 } & BTDO in feed [ppm] & toluene [\% ] & treated naphtha [\% ] & loss [\% ] & 0.85 \\
2 & 6.5 & 90.0 & 6.3 & 3.7 & 0.68 \\
3 & 6.6 & 93.0 & 3.6 & 7.4 & 0.55 \\
4 & 6.4 & 90.5 & 2.4 & 4.0 & 0.66 \\
\hline
\end{tabular}

a) Base on BTDO in feed.

b) Absorbed BTDO on SIL based on SIL at sulfur concentration of $10 \mathrm{ppb}$ on recovered Naphtha A.

Experimental conditions

SIL: $78.9 \mathrm{mg}$, Feed rate: $0.5 \mathrm{ml} / \mathrm{min}$, Total feed amount: $120 \mathrm{ml} / \mathrm{cycle}$, Recovery: recovered amount based on BTDO in feed. 


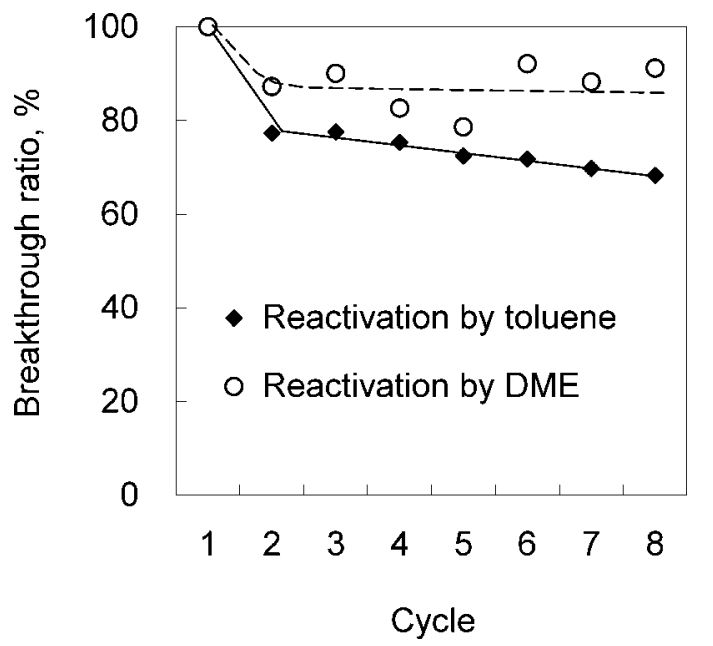

Fig. 4 Reactivation Effect on Breakthrough Ratio by Toluene and DME

activate the SIL, indicating that a more powerful solvent was required. However, a more powerful solvent could easily remain on the SIL and interfere with the adsorption of BTDO.

We thought that this could be avoided by using DME, which could be easily removed from the SIL as gaseous DME under reduced pressure. Figure 4 also shows the change in the breakthrough ratio using DME instead of toluene. The breakthrough ratio in the second cycle was $87 \%$, and this level was maintained throughout the experiment. The overall breakthrough ratio after 8 cycles was still approximately $87 \%$. The recovery of BTDO was not determined, but should be better than that with toluene after the second cycle. Those results indicate that DME is very effective at reactivating SIL.

In general, reactivating solvent requires the properties of good dissolution of BTDO from silica gel, easy desorption from silica gel to prevent the contamination of naphtha, and economic recovery. Solvents with weaker polarities than toluene, such as $n$-alkanes, are not suitable because of poor desorption. Solvents with high boiling points are not also suitable because too much heat is required for recovery by distillation. Polar solvents with low boiling points, such as tetrahydrofuran, are often used for reactivation ${ }^{10)}$. However, such solvents require a lot of coolant to remove sulfur oxides by distillation, which is quite costly in a commercial-scale process so should not be adopted.

A pressure swing process does not basically require any heating or cooling. Butane has been used, but desorption is quite limited. At the moment, DME is the only solvent with very polar properties but similar gasliquid behavior to butane. In addition, DME is expected to be available at a low price and in large quantities.

\section{3. Breakthrough Amount of SIL Reactivated by DME}

The above results suggest that DME would also be

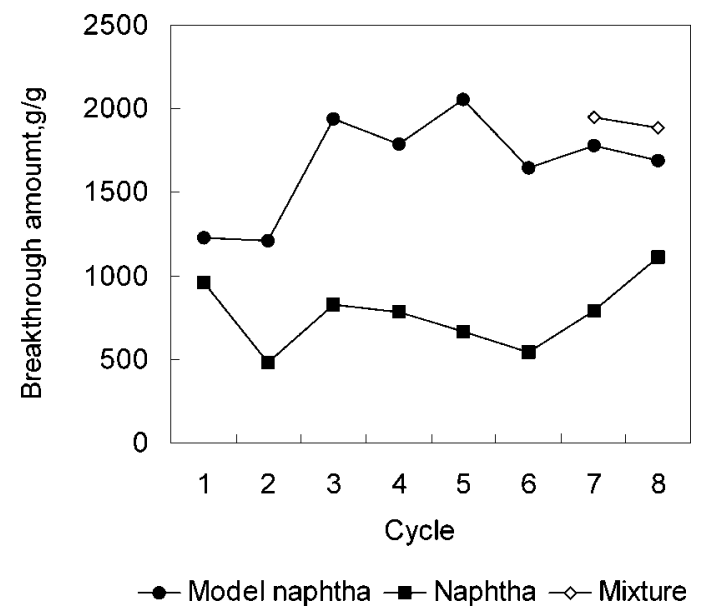

Fig. 5 Breakthrough Amount during Repeated Adsorption Test

effective for activating fresh SIL instead of drying. To investigate this idea, we performed an 8-cycle adsorptionreactivation test. Fresh SIL was activated using DME in the same process as for reactivation. The breakthrough amount using Naphtha $\mathrm{A}$ in the first two cycles was about $1200 \mathrm{~g} / \mathrm{g}-\mathrm{SIL}$, with the range of 1500-2000 g/ g-SIL after the third cycle (Fig. 5). These results indicate that DME is also effective for activating fresh SIL.

A similar test was performed using Naphtha B (Fig. 4). The breakthrough amount was less than for Naphtha A, but was as much as $500-1100$ g/g-SIL. A large amount of aromatic components probably prevented the adsorption of BTDO in Naphtha B.

Another test used naphtha prepared by mixing $50 \mathrm{wt} \%$ of Naphthas A and B, with an aromatic content calculated to be about $7 \mathrm{wt} \%$. After 8 cycles, the breakthrough amount was as much as $1880 \mathrm{~g} / \mathrm{g}$-SIL (Fig. 5), on the same level as that for Naphtha A. In the experiment, throughput was $1100-1500 \mathrm{~g} / \mathrm{g}$-SIL up to the 6th cycle. However, no breakthrough was observed on any cycle. In the last two cycles, throughputs of about $2000 \mathrm{~g} / \mathrm{g}$-SIL were conducted to obtain the breakthrough amounts, so only the last two cycles are shown in Fig. 5. The results show that an aromatic content of $7 \mathrm{wt} \%$ is sufficient to adsorb BTDO effectively.

Aromatics in naphtha are believed to act as desorption solvents. Certainly aromatics in Naphtha B, which contained $13.1 \mathrm{wt} \%$ of aromatics, suppressed the breakthrough amount. However, this is unlikely for naphtha containing about $7 \mathrm{wt} \%$ of aromatics, which can be achieved by dearomatization of naphtha.

\section{4. Multiple Adsorption-reactivation Performance}

The previous results demonstrated that SIL could be used for at least 8 cycles. This raised the question as to how many cycles would be practical if the throughput were limited to less than the breakthrough amount. Therefore, 25 cycles of the adsorption-reactivation test 


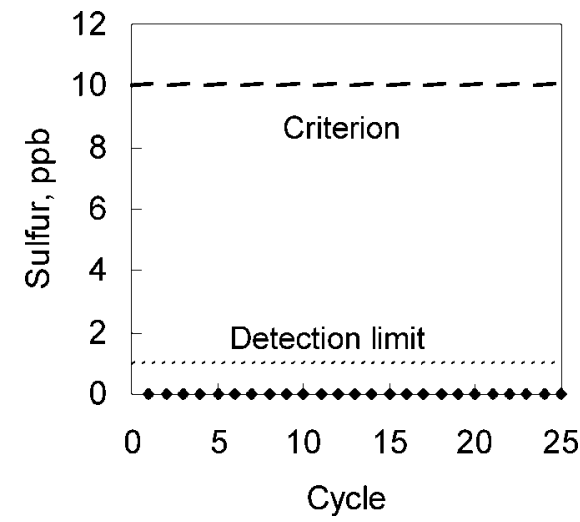

Fig. 6 Sulfur Concentration of Treated Model Naphtha during a 25-cycle Adsorption-reactivation Test
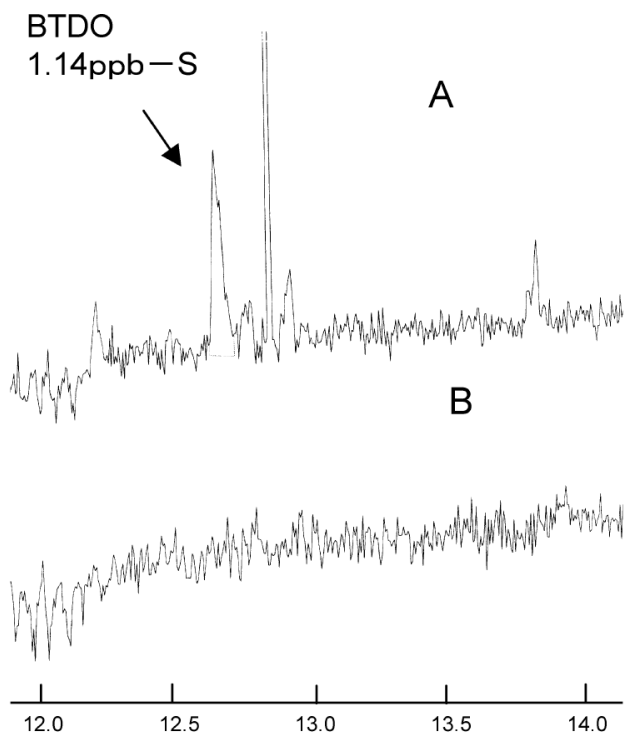

Retention time, $\min$

A : Reference sample (1.14 ppb sulfur concentration)

B: Treated Naphtha A at the 25 th cycle

Fig. 7 ICP-MS Spectra for Reference Sample (A) and Treated Naphtha A at the 25th Cycle

were conducted using Naphtha A, limiting the throughput to $1300 \mathrm{~g} / \mathrm{g}$-SIL. In addition, the amount of liquid DME for the reactivation was reduced to about $1.5 \mathrm{ml}$, which was about 15 times that of the SIL (vol/wt).

No BTDO was detected by the UV detector in any cycle, indicating that the BTDO concentration in the treated naphtha was lower than the detection limit of $1 \mathrm{ppb}$ of sulfur (Fig. 6). Additional analysis by gas chromatography/inductively coupled plasma mass spectrometry $(\mathrm{GC} / \mathrm{ICP}-\mathrm{MS})^{14)}$ of the treated naphtha at the 25 th cycle found no trace of BTDO, whereas analysis of the reference sample containing $5.7 \mathrm{ppb}$ of BTDO detected $1.14 \mathrm{ppb}$ of sulfur (Fig. 7). Therefore, the BTDO concentration in the treated naphtha was lower than the detection limit (1 ppb as sulfur). These results indicate that SIL could adsorb all BTDO in Naphtha A at a breakthrough amount up to $1300 \mathrm{~g} /$ g-SIL, and that the SIL could be reactivated by 15 times the volume of liquid DME.

Using DME in a large-scale process has some advantages. DME can reactivate SIL at ambient temperature, and at pressures below $1 \mathrm{MPa}$. The DME process requires no heat sources or other agents, and is a closed process involving pressure-swing. A process with a 1-week cycle period and a breakthrough amount of $1300 \mathrm{t} / \mathrm{day}$ would require only $7 \mathrm{t}$ of SIL for one cycle operation. Since such a process would require at least two adsorption units for continuous operation, it could be run for 50 weeks with two units. This means that operation for nearly one year would be possible with SIL.

\section{Conclusion}

The present study compared the use of liquid DME and toluene to activate SIL for the production of extra sulfur-free naphtha using a 4-cycle adsorptionreactivation test using Naphtha A containing $5 \mathrm{ppm}$ BTDO. The recovery of BTDO was more than $90 \mathrm{wt} \%$ using toluene as a reactivation agent, and 1.7-6.3 wt $\%$ of unadsorbed BTDO was recovered in treated Naphtha A. At the breakthrough point, the BTDO concentration on SIL was 0.55-0.85 wt \% . In an 8-cycle test using toluene, the breakthrough ratio decreased gradually every cycle, and the overall breakthrough ratio using toluene was $68 \%$ after 8 cycles starting with fresh SIL. In sharp contrast, using DME, the breakthrough ratio was maintained at $87 \%$ after 8 cycles. DME was also effective in activating fresh SIL.

The breakthrough amount of SIL was as high as 1300-1700 g/g-SIL for Naphtha A and 500-1000 g/ g-SIL for Naphtha B containing $13 \mathrm{wt} \%$ of aromatics. However, the breakthrough amount for the mixture of Naphtha A and B containing $7 \mathrm{wt} \%$ of aromatics was almost the same as for Naphtha A. These results suggest that SIL is suitable for naphtha types containing up to $7 \mathrm{wt} \%$ of aromatics.

Multiple adsorption-reactivation tests using Naphtha A were performed limiting the throughput to $1300 \mathrm{~g} /$ g-SIL. During 25 cycles, no significant amount of BTDO was observed in any of the treated naphtha. To reactivate the SIL, $15 \mathrm{ml} / \mathrm{g}$-SIL of liquid DME was sufficient.

These results suggest that 1-year operation is viable using a pressure-swing process with two adsorptionreactivation units operating in 1 -week cycles at ambient temperature. 


\section{References}

1) Song, C. S., Catal. Today, 86, 211 (2003).

2) Tawara, K., Nishimura, T., Iwanami, H., Hasuike, T., Sekiyu Gakkaishi (J. Jpn. Petrol. Inst.), 44, (1), 43 (2001).

3) Hernandez-Maldonado, A. J., Yang, R. T., Ind. Eng. Chem. Res., 43, 1081 (2004).

4) Ma, X., Sprague, M., Song, C. S., Ind. Eng. Chem. Res., 44, 5768 (2005).

5) Fukunaga, T., Katsuno, H., Matsumoto, H., Takahashi, O., Akai, Y., Catal. Today, 84, 197 (2003).

6) Shiraishi, Y., Hirai, T., Komasawa, I., J. Chem. Eng. Jpn., 35 1305 (2002).

7) Murata, S., Murata, K., Kidena, K., Nomura, M., Energy \&
Fuels, 18, 116 (2004).

8) Yazu, K., Makino, M., Ukegawa, K., Chem. Lett., 33, 1036 (2004)

9) Kabe, T., Ishihara, A., Qian, E. W., Jpn. Kokai Tokkyo Koho JP 2004-195445A.

10) Qian, E. W., J. Jpn. Petrol. Inst., 51, (1), 14 (2008).

11) Yazu, K., Sato, S., Sugimoto, Y., Matsumura, A., Saito, I., J. Jpn. Petrol. Inst., 50, (6), 329 (2007).

12) Sato, S., Yazu, K., Matsumura, A., J. Jpn. Petrol. Inst., 49, (4), 210 (2006).

13) Sato, S., Matsumura, A., J. Jpn. Petrol. Inst., 46, (6), 375 (2003).

14) Tao, H., Nakazato, T., Akasaka, M., Sato, S., Bunseki Kagaku, 56, 333 (2007)

要旨

\author{
ナフサ中の極微量硫黄酸化物の吸着分離 \\ 一シリカゲルのトルエンおよびジメチルエーテルによる再活性化一 \\ 松村 明光 $^{\dagger 1)}$, 矢津 一正 ${ }^{\dagger 1)}$, 佐藤 信也 ${ }^{\dagger 1)}$, 田尾 博明 ${ }^{\dagger 2}$ \\ †1) (独) 産業技術総合研究所 エネルギー技術研究部門新然料グループ，305-8569 茨城県つくば市小野川16-1 \\ †2） (独) 産業技術総合研究所 環境管理技術部門計測技術研究グループ，305-8569 茨城県つくば市小野川16-1
}

酸化脱硫により生成した硫黄酸化物のシリカゲル（SIL）の 反復利用の検討のため, $1 \mathrm{ppm}$ のベンゾチオフェン-1,1-ジオキ シド (benzothiophene-1,1-dioxide, BTDO) を含むモデルナフサ （Naphtha A）および水素化処理ナフサ（Naphtha B）の吸着, トルエンおよびジメチルエーテルによる再活性化を行った。

8 回の反復試験において, 吸着後の SIL をトルエンで再活性 化したところ，処理後のナフサの硫黄濃度が $10 \mathrm{ppb}$ となるま での破過容量は毎回低下し，8回反復後には初回の68\%まで低 下した。一方，ジメチルエーテル（DME）を用いた再活性化 では最初に $87 \%$ まで低下した後は破過容量の低下は見られず,
8 回の反復試験において 1300 ～ 1700 g/g-SIL であった。

同様の実験を芳香族含有量 $13 \mathrm{wt} \%$ Naphtha B で行った。 DME で再活性化した場合, 破過容量は500〜 1000 g/g-SIL に低 下したが, Naphtha A と B の 50\% 混合物では破過容量の低下 は起こらなかった。

Naphtha A を用いて処理量を 1300 g/g-SIL としたDMEでの 再活性化試験を 25 回繰り返した結果, すべての実験において 処理後のナフサの BTDO は検出限界（硫黄濃度は $1 \mathrm{ppb}$ 以下） であった。 